\title{
Phytochemistry and pharmacological activity of Scindapsus officinalis: A review
}

\author{
Pawan Tiwari*, Anju Goyal \\ Department of Pharmaceutical Chemistry, Bhupal Nobles' University, Udaipur, Rajasthan, India
}

\begin{abstract}
The herbal medicines are used in the ailment of several diseases from the ancient time. India is known worldwide for its Ayurvedic treatment. Scindapsus officinalis is often used traditionally for erectile disorders, respiratory diseases such as cough, bronchitis, pharyngitis, asthma and other worm infestation, dysentery, troubles of the throat, ozoena, rheumatism arthritis, and diarrhea. It is also used as carminative, anthelmintic, cardiotonic, diaphoretic, antiprotozoal (fruit), hypoglycemic (stem and fruit), anti-inflammatory, analgesic, antiasthmatic, cytostatic and antimicrobial steroids, flavonoids, and terpenoid which are characterized in the ethanolic extract of $S$. officinalis. This review describes the general information (distribution and plant description), description (macroscopic and microscopic), chemistry, ethnopharmacology, traditional uses, medicinal uses, and other important information about the plant S. officinalis.
\end{abstract}

Key words: Pharmacology, phytochemical, Traditional uses, Scindapsus officinalis

\section{INTRODUCTION}

$\mathrm{T}$ The genus Scindapsus Schott (1832) contains about 35 species from Northeastern India to Western Polynesia. It is an epiphytic climbing shrub, with ovateoblong, ovate-oblong cordate or oblonglanceolate leaves bisexual flowers and naked spathe. Florets are without perianth, each having four stamens and a one-celled ovary with a solitary basal ovule. About 15 species of the plant and numerous hybrids, all of which are evergreen, root clinging climbers with juvenile and adult stages, belong to this genus. The various species of genus Scindapsus include Scindapsus caudatus, Scindapsus decursivus Schott (Sylhet, Bangladesh), Scindapsus giganteus Schott (Penang, Singapore), Scindapsus glaucus Schott (Khasaya Paras, Nepal), Scindapsus officinalis Schott (India, Burma), Scindapsus peepla Endl (Sylhet, Bangladesh), Scindapsus pertusus Schott (Coromandel, South Konkan), Scindapsus pinnatifidus (Roxb.), Scindapsus pictus (S. pictus), Scindapsus scortechinii, Scindapsus hederacea, Scindapsus perakensis, Scindapsus crassipes, Scindapsus beccarii, and Scindapsus cuscuaria. $S$. officinalis, a plant with perennial stem, is a large epiphytic climber with adventitious aerial roots growing on trees and rocks. The mature inflorescence without the spathe is transversely sliced into pieces and dried and is commonly known as "Guj-pippul." In Ayurvedic system of medicine, it is known to cure "atisara" (diarrhea), "svasa" (dyspnea), "kanthmaya" (throat diseases), and "krimi" (parasitic infestation) ${ }^{[1-4]}$

\section{TAXONOMICAL CLASSIFICATION}

The botanical name of Gajapippali is S. officinalis (Roxb) Schott. It belongs to plant family Araceae. Below is given taxonomical classification of plant.

- Kingdom: Plantae

- Phylum: Magnoliophyta

- Class: Liliopsida

- Order: Alismatales

- Family: Araceae

- Genus: Scindapsus Schott

- Species: Scindapsus officinalis (Roxb)Schott

\section{MORPHOLOGICAL DESCRIPTION}

Traditional medicine based on herbal remedies has played a key role in the health system of many countries. The value

\author{
Address for correspondence: \\ Mr. Pawan Tiwari, Rsearch Scholar, Bhupal Nobles' \\ University, Udaipur, Rajasthan, India. \\ Phone: +91-7073956690. \\ E-mail: pawan786pharma@gmail.com
}

Received: 22-07-2018

Revised: $16-10-2018$

Accepted: 15-11-2018 
and importance of traditional knowledge are now being increasingly all over the world. In India, between 2500 and 500 BC, Ayurvedic concept appeared. The literal meaning of Ayurveda is "science of life," because ancient Indian system of health care focused views of man and his illness. Of the 2, 50,000 higher plant species on earth, more than 80,000 are medicinal. India is one of the world's 12 biodiversity centres with the presence of over 45000 different plants. The leaves of S. officinalis are large (upto $25 \mathrm{~cm}$ long), leathery, with dark green peduncle. They are solitary with terminal much shorter than the petiole. Their shape is ovate, elliptic ovate or nearly orbicular, caudate acuminate with rounded or slightly cordate base. The primary nerves are distinct, marked with the presence of dilated or winged petiolar sheaths. The stem of the plant is as thick as a little finger and turns almost woody when old. The roots of the plant are adventitious and aerial, clinging on trees and rocks [Figure 1].

\section{VERNACULAR NAMES/SYNONYMS}

1. Sanskrit: Gajakrishna, Hastipipali, Gajapippali, Karipippali, and Kolavalli

2. Siddha: Anaitippili

3. Bengali: Gajapeepal and Gajapipul

4. Gujarati: Motopeepar

5. Hindi: Gajapeepa.

\section{TRADITIONAL AND CONTEMPORARY USES}

According to Ayurveda, S. officinalis is used to treat "atisara" (diarrhea), "svasa" (dyspnea), "Krimiroga" (worm infestation), and "kanthyaroga" (throat infections). According to Ayurveda, the pharmacodynamics of the plant is explained by "Rasa" (taste), "Guna" (property), "Virya" (potency), "Vipaka" (post-digestive effect), and "Karma" (pharmacology). The taste of the plant is pungent, with dry and sharp properties. The roots have hot ("Ushna") potency

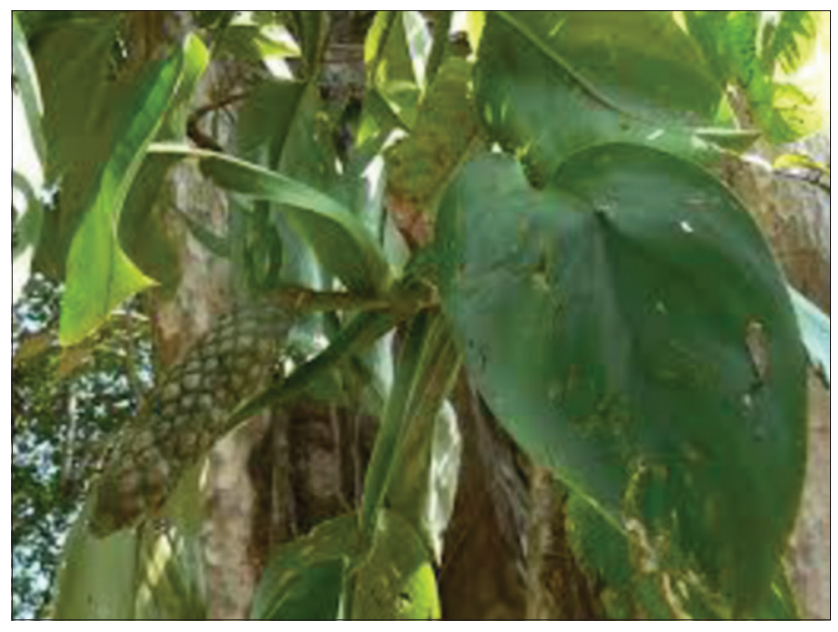

Figure 1: Scindapsus officinalis plant with fruit and the fruits have cold ("Sheeta") potency. The fruits have sweet post-digestive effect. ${ }^{[5]}$ The pharmacological activities of the plant include "Dipana" (increasing appetite), "Agnivardhak" (peptic), treating "Kanthya" (throat infections), "Kaphahara" (productive cough), "Stanya" (breast problems), and "Varnya" (improving skin complexion). ${ }^{[6]}$

\section{Phytochemistry}

The fruits contain two glycosidic substances - scindapsin A and scindapsin B which on hydrolysis yield aglycon, sugars such as rhamnose, fructose, glucose, and xylose together. Fixed oil, which present in fruits are 1l-hydroxy-cis, cis5,8- tetracosadienoic acid, cyclopropenoid fatty acids, piperine, mixture of glycerine and ascorbic acid, and ascorbic acid. ${ }^{[1,7]}$

The structures of scindapsin $\mathrm{A}$ and scindapsin $\mathrm{B}$ are $\mathrm{C}_{26} \mathrm{H}_{32} \mathrm{O}_{14}$ and $\mathrm{C}_{31} \mathrm{H}_{28} \mathrm{O}_{13}$, respectively, which on hydrolysis yield the aglucones scindapsinidine $\mathrm{A}\left(\mathrm{C}_{25} \mathrm{H}_{16} \mathrm{O}_{7}\right)$ and scindapsinidine B $\left(\mathrm{C}_{20} \mathrm{H}_{22} \mathrm{O}_{9}\right)$, respectively. A sterol $\left(\mathrm{C}_{30} \mathrm{H}_{50} \mathrm{O}_{2}\right.$, m.p.2700 decomp.) and three unidentified colorless substances $\left(\mathrm{C}_{20} \mathrm{H}_{28} \mathrm{O}_{3}, \mathrm{C}_{18} \mathrm{H}_{24} \mathrm{O}_{4}\right.$, and $\left.\mathrm{C}_{17} \mathrm{H}_{30} \mathrm{O}_{3}\right)$ have also been isolated from the fruit extract. A new hydroxy fatty acid characterized as 11-hydroxy-cis, cis-5,8- tetracosadienoic acid along with cyclopropenoid fatty acids are also one chemical compounds present in the oils of $S$. officinalis which are identified by some spectroscopic techniques such as infrared (IR), nuclear

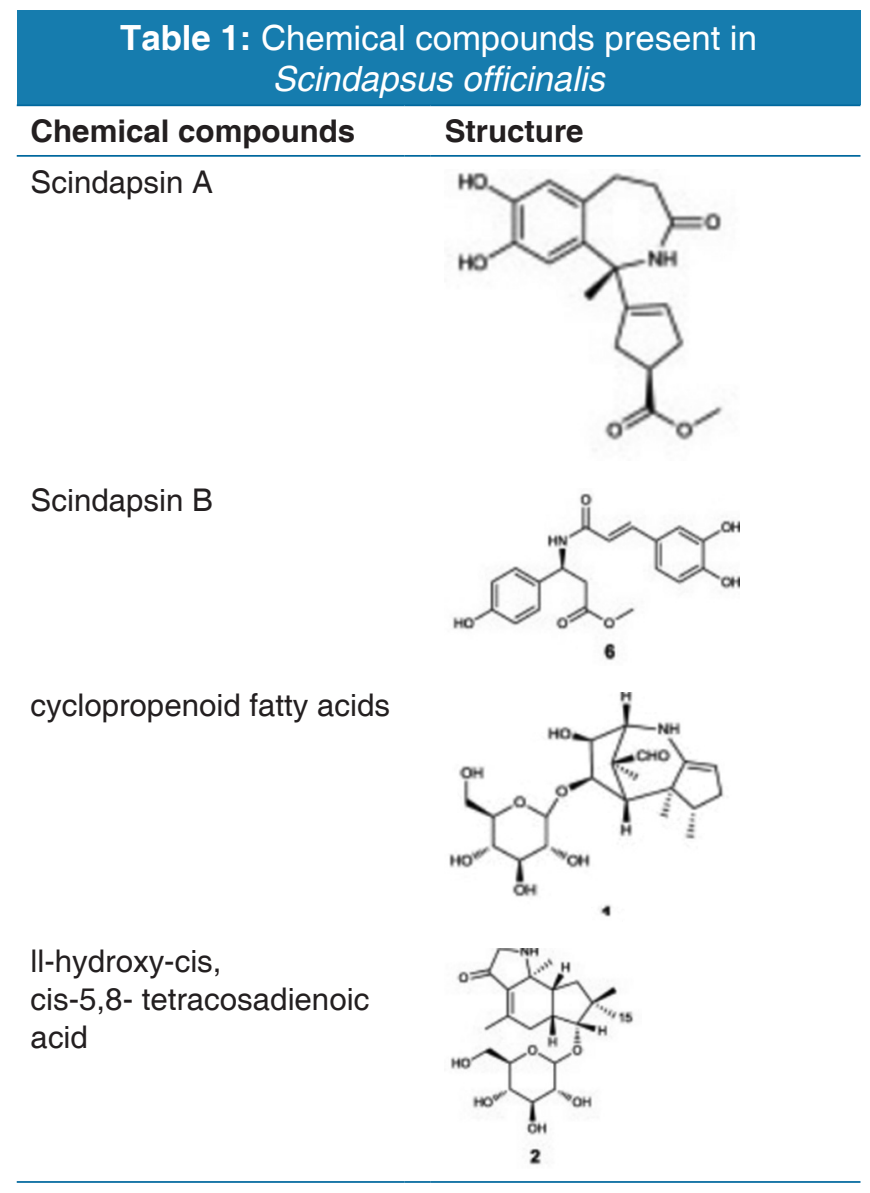


Table 2: Biological properties of Scindapsus officinalis (Roxb.) in different extracts

\begin{tabular}{|c|c|c|c|}
\hline Pharmacological activities & Plant part & Extract & Compound \\
\hline Hepatoprotective activity & Fruit & Hydroalcoholic extract & $\begin{array}{l}\text { II-Hydroxy-cis, cis-5,8- tetracosadienoic } \\
\text { acid }\end{array}$ \\
\hline Anthelmintic activity & Fruit & Aqueous extract & $\begin{array}{l}\text { II-Hydroxy-cis, cis-5,8- tetracosadienoic } \\
\text { acid }\end{array}$ \\
\hline $\begin{array}{l}\text { Analgesic and anti-inflammatory } \\
\text { activities }\end{array}$ & Fruit & Methanolic extract & $\begin{array}{l}\text { II-Hydroxy-cis, cis-5,8- tetracosadienoic } \\
\text { acid }\end{array}$ \\
\hline Anticancer activity & Fruit & Methanolic extract & $\begin{array}{l}\text { II-Hydroxy-cis, cis-5,8- tetracosadienoic } \\
\text { acid }\end{array}$ \\
\hline
\end{tabular}

magnetic resonance, mass spectrometry (MS), and chemical degradation [Tables 1 and 2]. ${ }^{[8,9]}$

\section{Pharmacological Activity}

\section{Antioxidant activity}

Coarse powder of S. officinalis (Roxb.) Schott. fruit was extracted successively using hexane, chloroform, ethyl acetate, and 50\% ethanol. The ethyl acetate and 50\% ethanolic extracts were investigated for its antioxidant activity using nitric oxide and 2,2-diphenyl-1-picrylhydrazyl radical scavenging methods. The IC value was also calculated and ascorbic acid w 50 as used as standard. Both the 50\% ethanolic and ethyl acetate extract were found to exert concentration-dependent free radical scavenging activity, but former extract was more effective than the later on. The highest free radical scavenging activity by $S$. officinalis fruit extracts was observed at a concentration of $1000 \mu \mathrm{g} / \mathrm{ml} .^{[10]}$

\section{Antidiabetic activity}

Ethyl acetate (EAESOF) and ethanolic (EESOF) extract of $S$. officinalis fruit were subjected to the phytochemical investigation and evaluated for antidiabetic activity on blood glucose level, lipid profiles, and on the body weight in alloxan-induced diabetic rats. EAESOF and EESOF (200 mg/ $\mathrm{kg})$ and glibenclamide $(10 \mathrm{mg} / \mathrm{kg})$ were administered orally in alloxan $(120 \mathrm{mg} / \mathrm{kg}$, i.p.) induced diabetic rats. In this antidiabetic study, maximum reduction in blood glucose was observed in EAESOF and EESOF $(160.8,96.7 \mathrm{mg} / \mathrm{dl})$ at the dose of $200 \mathrm{mg} / \mathrm{kg}$ on $21^{\text {st }}$ day, respectively. The EAESOF and EESOF showed the significant effect $(P<0.005)$ in the various biochemical parameters such as protein, triglycerides, cholesterol, and total lipid levels. EAESOF and EESOF prevented further loss of body weight. EAESOF and EESOF $(200 \mathrm{mg} / \mathrm{kg})$ were found to have significant $(P<0.001)$ blood glucose lowering effect. Preliminary phytochemical investigation revealed the presence of alkaloids, flavonoids, saponins, and tannins as the major constituents in the ethyl acetate and ethanol extract. These results suggest that EAESOF and EESOF $(200 \mathrm{mg} / \mathrm{kg})$ showed antidiabetic activity in alloxan-induced diabetic rats. ${ }^{[11]}$

The fruit was further subjected to antidiabetic study through six segment method and was investigated for antihyperglycemic effects in long Evans rats. The antidiabetic effects were estimated by measuring the amount of glucose in the samples, collected from six different segments of the gut, after the experiment. The amount of sucrose unabsorbed in different GIT segments were evaluated in control rats versus rats fed with $500 \mathrm{mg} / \mathrm{kg}$ extract at $30 \mathrm{~min}, 1 \mathrm{~h}, 2 \mathrm{~h}$, and $4 \mathrm{~h}$. Phytochemical analysis of the ethanolic extract of $S$. officinalis has indicated the presence of steroid, carbohydrate, flavonoid, alkaloid, tannin, saponin, and terpenoid-compounds. The extract caused a significant $(P<0.05)$, dose-dependent inhibition of glucose absorption and showed hypoglycemic effects in rats weighing from 80 to $200 \mathrm{~g}$. In conclusion, these observations provide evidence and possible mechanisms of action for the medicinal properties of fruit of $S$. officinalis claimed in Ayurveda medicine. ${ }^{[12]}$

\section{Anticancer activity}

S. officinalis (Roxb.) Schott fruits extract was evaluated for antioxidant and anticancer activity. An in vitro cytotoxic assay using the brine shrimp lethality assay with brine shrimp eggs (Artemia salina) at a dose of $1-10 \mu \mathrm{g} / \mathrm{ml}$ with the fruit extract was performed by the method described by Mayer et al. Cell viability using the Trypan blue dye exclusion test at a dose of 20, 40, 80, 120, and $160 \mu \mathrm{g} / \mathrm{ml}$ dissolved in dimethyl sulfoxide (final concentration $0.1 \%$ ), and cytotoxicity using the MTT assay where viable cells convert MTT into a formazan salt were performed. All pharmacological screening for acute toxicity and antitumor studies using EAC $1 \times 106$ cells/mouse treated Swiss albino mice at a dose of 100 and $200 \mathrm{mg} / \mathrm{kg}$ /day orally was carried out. Biochemical and antioxidants predictions from various parameters such as hematological, red blood cells, white blood cells count, packed cell volume, total protein, tissue lipid peroxidation, superoxide dismutase (SOD), CATALASE, glutathione peroxide (GPx), glutathione - S - transferase (GST) levels, and antitumor activity of $S$. officinalis were observed. The data were statistically analyzed by one-way ANOVA followed by Dunnett's and Tukey's multiple comparison test. The antitumor effect of the extract is evident from the increase in mean survival time lifespan, reduction in the solid tumor volume, and also the reversal of altered hematological parameters almost equal to normal. The methanolic extract (100-200 mg/kg/day orally) was found to be cytotoxic on 
human cancer cell lines. In addition, the methanolic extract had an antioxidant effect as reflected by a decrease in LPO, GST, and GPx (oxidant enzymes), and an increase in SOD and catalase. ${ }^{[13]}$

\section{Analgesic and Anti-inflammatory Activities}

Methanol extract of the root of $S$. officinalis (200, 400, and $600 \mathrm{mg} / \mathrm{kg}$ ) was evaluated for analgesic and antiinflammatory activities using acetic acid-induced writhing, hot plate, carrageenan-induced-inflammation, and cotton pellet-induced granuloma method. The methanol extract exhibited significant $(P<0.001)$ inhibition of acetic acidinduced writhing in mice and a significant $(P<0.001)$ dosedependent increase in latency time. The methanol extract also produced a significant $(P<0.001)$ anti-inflammatory effect in a dose-dependent manner in carrageenan-induced inflammation which is comparable to that of the reference drug diclofenac sodium $(10 \mathrm{mg} / \mathrm{kg}) .{ }^{[13,14]}$

The experimental activities for the ethanolic extract of S. officinalis fruit exhibited statistically significant $(P<0.05)$ anti-inflammatory activity in Carrageenan-induced Hind Paw Edema in long Evans rat and statistically significant $(P<0.05)$ analgesic activity in Swiss albino mice in a dose-dependent manner. In conclusion, these observations provide evidence and possible mechanisms of action for the anti-inflammatory and analgesic properties of fruit of $S$. officinalis claimed in Ayurveda medicine. Further studies should be undertaken to correlate the pharmacological activities with the chemical constituents of the fruit of S. officinalis. ${ }^{[14,15]}$

\section{Anthelmintic activity}

In vitro anthelmintic efficacy of an aqueous extract of S. officinalis (Roxb.) Schott fruits was evaluated against Haemonchus contortus of small Ruminants. ${ }^{[15-17]}$

\section{Antiasthmatic activity}

Methanolic extract of fruit of Scindapsus officinalis (MESO) showed the antihistaminic (H1 receptor antagonist) activity. In-vivo and in-vitro models such as Histamine-induced Bronchospasm in Guinea pigs and Isolated Guinea pig ileum preparation respectively were used to evaluate the antiasthmatic activity. In-vitro study, increase in the contractile responses of the tissues significantly at the different doses of 50, 100 and $200 \mu \mathrm{g} / \mathrm{ml}$. In-vivo study, different doses of 50, 100 and $200 \mu \mathrm{g} / \mathrm{ml}$ of MESO showed the significant increase in preconvulsion time. Alkaloids, tannins, saponins, flavonoids, glycosides, phenolic compounds, terpenoids and steroids were reported in MESO extract. ${ }^{[18-20]}$

\section{Antimicrobial activity}

Methanolic extract of Scindapsus officinalis (MESO) were assayed for activity against eleven strains of bacteria and four strain of fungi. Fruit of Scindapsus officinalis show the antibiotic, and the antiviral potential. No zone of inhibition are shown in Bacillus subtilise, Staphylococcus aureusmethicilin resistant, Streptococcus faecalis, Pseudomonas aeruginosa-sensitive, Pseudomonas aeruginosa-wild type, Mycobacterium phlei, Saccharomyces cerevisiae, and Candida albicans. MESO are active only one strain of fungi as Trichophyton mentagrophytes. MESO are active only when exposed to UV light only one Gram-positive strain of Staphylococcus aureus-methicilin sensitive.

\section{Cytostatic activity}

Ethanolic extract of Scindapsus officinalis in concentration of $200 \mu \mathrm{g} / \mathrm{ml}$ were tested for cytotoxicity on COLO 320 tumour cells, using the microculture tetrazolium (MTT) assay. The IC50 - value, the concentration causing 50\% growth inhibition of the tumour cells, was used as a parameter for cytotoxicity. The extracts of Scindapsus officinalis did not show a cytotoxic effect up to $100 \mu \mathrm{g} / \mathrm{ml}$, the highest concentration tested. The value of IC $50(\mu \mathrm{g} / \mathrm{ml})$ of fruit of Scindapsus officinalis was found to be $38 \pm 1$ and Growth inhibition at $100 \mu \mathrm{g} / \mathrm{ml}(\%)$ was 93.50 .

\section{Antiviral activity}

Methanolic extract of fruits were assayed in two in vitro viral systems, influenza virus/MDCK cells and herpes simplex virus/vero cells and IC50 value was calculated. These extract showed no cytotoxic effects. The IC50 $(\mu \mathrm{g} / \mathrm{ml})$ was $87 \mathrm{using}$ test system Influenza A/MDCK cells and CC50 $(\mu \mathrm{g} / \mathrm{ml})$ not measured. The CC50 $(\mu \mathrm{g} / \mathrm{ml})$ was 33.3 using test system stimulant.

\section{CONCLUSION}

This review shows that $S$. officinalis (Roxb.) is an important medicinal plant with diverse pharmacological spectrum. Few novel chemical constituent isolated from S. officinalis (Roxb.) showed anticancer, antidiabetic, and antiulcer properties too. Further evaluation need to be carried out on S. officinalis (Roxb.) to explore concealed areas and their practical clinical application, which can be used for the welfare of the mankind port in carrying out this study at the laboratory.

\section{REFERENCES}

1. Chirag D. A new hydroxy fatty acid from Scindaspus officinalis seed oil. Int J Food Sci Technol 1992;27:77-9.

2. Velraj M, Singh M. Pharmacognostical study on the fruits of Scindapsus officinalis (Roxb.) Schott. (Araceae). Int J Pharm Pharm Sci 2012;5:441-6.

3. KaushikD,KaushikP.Scindaspus officinalis:A comparhensive review. Int J Pharm 2012;2:18-27.

4. Vikram P. Scindaspus officinalis fruit a phytochemical and pharmacological review. World J Pharm Pharm Sci 2014;3:2626-36.

5. Sudarshan SR, Parameshvara V. Encyclopaedia of Indian 
medicine: Materiamedica Herbal Drugs. Mumbai: Popular Prakashan; 2005.

6. Anonymous. The Ayurvedic Pharmacopoeia of India. Vol. 3. New Delhi: Government of India Ministry of Health and Family Welfare, Department of Ayush; 2001. p. 42.

7. Velraj M, Singh M. Isolation and characterization of constituents from ethanolic extract of Scindapsus officinalis (ROXB.) Schott. Bull Pharm Res 2014;4:67-71.

8. Kirtikar KR, Basu BD. Indian medicinal plants with illustration. Oriental Enterprises, Dehradun, India 2003.

9. Singh M, Velraj M. In-vitro evaluation of Scindaspus officinalis (Roxb.) schottfruit for antioxidant potential. Afr J Basic Appl Sci 2009;1:83-6.

10. Velraj M, Singh M. Antidiabetic activity of ethyl acetate and ethanolic extract of Scindaspus officinalis fruit in alloxan induced dibeticrats. Int $\mathrm{J}$ Pharm Res 2011;3:1305-10.

11. Ferdous N, Hridi S. Phytochemical analysis and hypoglycemic potential of Scindaspus officinalis (Roxb.) schott in laboratory animals via disaccharide absoption inhibition in GI. Int J Curr Res Acad Rev 2013;1:17-25.

12. Shivhare SC, Patidar A. Antioxidant and anticancer evaluation of Scindaspus officinalis (Roxb) Schott fruits. Int Q J Res Ayurveda 2011;32:388-94.

13. Mishra SK, Satapathy KB. Analgesic and antiinflammatory activity of methanol extract of Scindapsus officinalis Root in experimental animal.
Pharmacologyonline 2011;3:396-411.

14. Ferdous N, Hridi SU. Studies on the anti-inflammatory and analgesic efficacy of Scindapsus officinalis (roxb.) schott in laboratory animals. Int J Pharm Sci Res 2013;4:1434-41.

15. Shrivastava N, Agrawal P. Hepatoprotective activity of Scindaspus officinalis Fruit in paracetamol induced hepatotoxicity in rats. Int J Pharm Sci Res 2013;4:1598-609.

16. Singh $\mathrm{G}$, Rajeev S. In vitro anthelmintic efficacy of aqueous extract of Scindapsus officinalis (Roxb.) Schott. Fruit against Haemonchus contortus of small Ruminants. Springer 2015;85:705-9.

17. Kokate CK, Purohit AP, Gokhale SB. Pharmacognosy. $1^{\text {st }}$ ed. Pune: Nirali Prakashan; 1990. p. 23.

18. Rangari VD. Pharmacognosy and Phytochemistry. $1^{\text {st }}$ ed. Pune: Career Publication; 2003,

19. Patel BD, Shekhar R, Sharma P, Singh A, Tyagi S, Singh RK, Shakya YS. Antiinflammatory inflammatory and analgesic activity of Scindapsus officinalis (ROXB.) Schott. Am-Eur J Toxicol Sci 2010;2:158-61.

20. Hedaytullah, MD, Arya GS, Raghvendra, Singh N, Mishra A, Chaturvedi P. Evaluation of anti-asthmatic activity of methanolic extract of the fruit of Scindapsus officinalis (Roxb.) Schott. Adv Biol Res 2010;4:305-8.

Source of Support: Nil. Conflict of Interest: None declared. 